\title{
APPLICATION OF OZONE-SLURRY ICE COMBINED SYSTEM FOR MAINTAINING THE FRESHNESS OF RED TILAPIA AND SHORT-BODIED MACKEREL DURING COLD STORAGE
}

\author{
Tri Winarni Agustini ${ }^{1 \star}$, Muhammad Nur ${ }^{2}$, Endang Kusdiyantini ${ }^{3}$ \\ ${ }^{1}$ Department of Fisheries, Faculty of Fisheries and Marine Science, Diponegoro University, Tembalang \\ Campus, Jl. Prof. Soedharto, SH, PO Box 50275, Semarang Indonesia \\ ${ }^{2}$ Department of Physics, Faculty of Science and Mathematics, Diponegoro University, Tembalang \\ Campus, Jl. Prof. Soedharto, SH, PO Box 50275, Semarang Indonesia \\ ${ }^{3}$ Department of Biology, Faculty of Science and Mathematics, Diponegoro University, Tembalang \\ Campus, Jl. Prof. Soedharto, SH, PO Box 50275, Semarang Indonesia \\ ${ }^{*}$ Corresponding author: tagustini@yahoo.com \\ Recieved: June, $3^{\text {th }}$ 2017/ Accepted: August, $20^{\text {th }} 2017$
}

Citation: Agustini TW, Nur M, Kusdiyantini E. 2017. Application of ozone-slurry ice combined system for maintaining the freshness of red tilapia and short-bodied mackerel during cold storage. Jurnal Pengolahan Hasil Perikanan Indonesia. 20(2): 424-431.

\begin{abstract}
Application of ozone combined with the chilling system on preserving fresh fish has obviously brought about more advantages. This study observed the application of an ozone-slurry ice combined system for maintaining the freshness of two different fishes during storage. The fishes used were red tilapia (Oreochromis niloticus) and short-bodied mackerel (Scomberomorus rastrelliger), using ozone and slurry ice. The experimental design used was factorial using a completely randomized design employed with an ozone concentration of $0 \mathrm{ppm}$ and $3.5 \mathrm{ppm}$ with storage times of $0,4,8,12$, and 16 days. The parameters observed included: peroxide value (PV), total volatile base nitrogen (TVBN), total viable count (TVC), and a sensory test. The parametric data were analyzed using ANOVA and followed by least significant difference (LSD), whereas the non-parametric data were analyzed using the Kruskal Wallis test followed by multiple comparison tests. Ozone and slurry ice treatment of different concentrations had a significant $(p<0.05)$ effect on the TVBN, the PV, and the TVC. The interaction of ozone and slurry ice provided no significant difference( $p>0.05)$ in both samples.A sensory evaluation in both samples showed good correlation with TVC. This study showed that ozone and slurry ice could maintain the samples freshness during storage.
\end{abstract}

Keywords: fish freshness, storage, Oreochromis niloticus, ozone treatment, Scomberomorus rastrelliger

\section{Aplikasi Sistem Kombinasi Larutan Ozon-Es untuk Mempertahankan Kesegaran Ikan Nila dan Ikan Kembung Selama Penyimpanan Dingin}

\begin{abstract}
Abstrak
Penerapan ozon yang dikombinasi dengan sistem pendinginan dalam pengawetan ikan segar telah terbukti memberikan kemanfaatan lebih terhadap daya awet ikan segar. Studi ini bertujuan untuk mengamati pengaruh aplikasi ozon dalam bentuk larutan (slurry) yang dikombinasikan dengan es dalam mempertahankan kesegaran dua jenis ikan selama penyimpanan. Jenis ikan yang digunakan adalah ikan nila (Oreochromis niloticus) dan ikan kembung (Scomberomorus rastrelliger). Rancangan penelitian yang digunakan adalah rancangan factorial dengan Rancangan acak lengkap serta menggunakan perlakuan konsentrasi ozon yang berbeda: $0 \mathrm{ppm}$ dan $3.5 \mathrm{ppm}$ selama penyimpanan $0,4,8,12$, dan 16 hari. Parameter yang diamati mencakup Nilai peroksida (PV), Total volatile basa nitrogen (TVBN), total bakteri (TVC), dan uji sensori. Data parametrik dianalisa dengan ANOVA dan diikuti dengan Uji beda nyata terkecil (LSD), sedangkan data non parametrik dianalisa dengan Kruskal Wallis test yang diikuti dengan uji multiple comparison. Perbedaan konsentrasi ozon dan larutan es berpengaruh nyata $(\mathrm{p}<0.05)$ terhadap TVBN, PV,dan TVC. Interaksi antara ozon dan larutan es memberikan perbedaan yang tidak nyata $(p>0.05)$ pada kedua sampel. Berdasarkan pengamatan sensori pada kedua sampel, menunjukkan bahwa terdapat korelasi
\end{abstract}


bagus dengan TVC. Studi ini menunjukkan bahwa ozon dan larutan es dapat mempertahankan kesegaran ikan selama penyimpanan.

Kata kunci: ikan nila, ikan kembung, kesegaran ikan, penyimpanan, perlakuan ozon

\section{INTRODUCTION}

Fresh fish should always be treated to ensure a high-quality product suitable for consumption. The period from catching the fish to delivering to the consumer has an important effect on the nutritional value and characteristics of the fish. In modern food technology, fish are highly perishable. Red tilapia and short-bodied mackerel are extremely perishable fish due to their highwater content, high levels of non-protein nitrogenous substance, unsaturated fatty acid, and microbial activity and other less important oxidative reactions that occur during storage. In consideration of these characteristics and to avoid the degradation of fish quality (for twelve hours) (Nurjanah et al. (2004)), combining ice slurry and ozone as a preservation method has drawn much attention. Ice slurry, or slush ice, represents a refrigeration system used for traditional chilling and consists of an ice water suspension at a subzero temperature. The advantages of using ice slurry include a faster chilling rate compared to traditional chilling systems with flaked ice or chilled water, and reduced physical damage to the fish products (Pineiro et al. 2004).

Ozone is a bactericidal agent and a promising technique for fish preservation, as many researchers have developed ozone applications for fish preservation (Manousaridis et al. 2005; Campos, 2006; Pastoriza et al. 2008; Crowe et al. 2012; Bono and Badalucco, 2012). Every species of fish has a specific characteristic and quality, so it is challenging to provide ozone application for different fish species and use a method that provides maximized results. In this research, we used ozone combined with an ice slurry for red tilapia (Oreochromis niloticus) and shortbodied mackerel (Scomberomorus rastreligger). Two species of fish were used in this research because of their different living habitats, namely, red tilapia comes from freshwater and short-bodied mackerel come from the ocean. Nevertheless, from nutritional and economic value aspects, the two species are very important fishery resources in Indonesia. Reported in Leksono (2001) the nutrient content from the $100 \mathrm{~g}$ meat of red tilapia was $43.76 \%$ protein, $7.01 \%$ lipids, and $6.80 \%$ ash. Mackerel also contains large sources of omega-3 polyunsaturated fatty acids (PUFAs) which are healthy for human consumption. Many researcher shaves declared many benefits of PUFAs from marine species regarding the coronary disease, cardiovascular disease, and their effect to minimize depression (Delgado et al. 2012 and Perica et al. 2011). Based on Ministry of Maritime Affairs and Fisheries $\left(2015^{\mathrm{a}}\right)$ the production of red tilapia from 2010 to 2014 increased $21.41 \%$ and in 2015 the production volume was 592.366 tons. Reported in Ministry of Maritime Affairs and Fisheries $\left(2015^{\mathrm{b}}\right)$, Indonesian export commodities of mackerel in January-October 2015 increased $101.98 \%$ to US\$ 31.53 million with a volume of 17.19 million tons, whereas in the same period in 2014 it was US\$ 15.61 million with a volume of 9.23 million tons. Therefore, the quality of freshness of the two, fish species should be maintained. The quality of freshness could be assessed by chemical analysis (total volatile base nitrogen (TVBN) and peroxide value (PV)) and microbiological analysis (Total Viable Count). The purpose of this research was to determine the optimum conditions for ozone treatment, that is, correctly combining the methods using ozone and ice slurry and also ozone dosages for maximizing the shelf-life of the two species.

\section{MATERIALS AND METHODS Preparation of samples}

Fresh red tilapia (Oreochcromis niloticus) and short-bodied mackerel (Scomberomorus rastreligger) with bone-in and a weight of $18 \mathrm{Kg}$ (240-260 g; 22.5-24 cm) were each divided into two groups. Fish has been brought into the water to the laboratory in living conditions using an open system. Fish in the laboratory is immediately slaughtered 
in the medulla oblongata to inhibit fish quality decomposition. Nine $\mathrm{kg}$ from the two, fish species are stored in a 60-Lice slurry (water: ice $=3: 2$ ), and every 24 hours the ice was replaced.

First group: the samples were injected with ozone $(3.5 \mathrm{ppm})$ for $90 \mathrm{~min}$. The next injection occurred every 12 hours for a duration of 16 days of storage with the levels of ozone and duration of injection same as previous (90 min). The freshness quality of the samples was observed for 16 days and every four days they were analyzed in the laboratory. Second group: the samples were stored in an ice slurry for $90 \mathrm{~min}$ and the freshness quality was observed in samples every $30 \mathrm{~min}$.

\section{Chemical analysis}

The PV was determined by AOCS (1995), with samples filtrated into glacial acetic acid and chloroform reacted with KI. Iodine was released and titrated with the standard solution (Sodium Thiosulfate). The TVBN was performed according to the Indonesian National Standard 2354.8:2009. Briefly, 25 g samples were weighed and then mixed with $75 \mathrm{~mL}$ of TCA (7\%). The filtrates $(1 \mathrm{~mL})$ were placed in a conway cup of the outer chamber which had previously been added to $1 \mathrm{~mL}$ $\mathrm{K}_{2} \mathrm{CO}_{3}$, another Conway cup of the inner chamber added $1 \mathrm{~mL}$ Boric acid and 2-3 drops of indicator (screen metal red) until it turned green. Blanko had been used $1 \mathrm{~mL}$ TCA 7\%. The Conway cup incubated at $37^{\circ} \mathrm{C}$ for $2 \mathrm{~h}$. The Conway cup in the inner chamber of the blank was titrated with $\mathrm{HCl}$ until it turned pink. The Conway cup of the samples was titrated with boric acid until its turn equal with a blank.

\section{Microbiological analysis}

A microbiological assessment known as the total viable count (TVC), is used to assess the freshness quality of the fish. The TVC was based on the Indonesian National Standard 01-2332.3-2013. For microbial enumeration, $10 \mathrm{~g}$ of the samples was weighed under aseptic conditions and then mixed with $90 \mathrm{ml}$ peptone water. Next, it was homogenized in a stomacher (Seward Medical, London, UK). Prepared serial dilutions $(1 \mathrm{~mL}, 0.1 \mathrm{~mL}$, and $0.01 \mathrm{~mL}$ ) from the microbial extract were prepared in three serial peptone water. The TVC was determined using a plate count agar (PCA, Merck) method, from the three serial dilutions that were spread in the PCA and then incubated for $48 \mathrm{~h}$ at $30^{\circ} \mathrm{C}$.

\section{Sensory Analysis}

Sensorial attributes from the samples were evaluated by ten experienced panelists. The sensory evaluations were conducted in individual booths under controlled conditions of light, temperature, humidity, and avoid satiety condition from each panelist. The panelists were asked to provide a score of appearance, taste, odor, and texture from the samples using a 1-9 acceptability scale (Indonesian National Standard 2729:2013).

\section{Statistical Analysis}

Data from the experiment (TVBN, PV, and TVC) were analyzed using the analysis of variance design split plot as a function of time. The analysis was run in two tries with a significance level of $95 \%$, and further analysis was performed using the least significant difference (LSD) procedure. Data from the sensory analysis was analyzed using the nonparametric test (Kruskal Wallis), All analyses were performed using SPSS ver. 20 software.

\section{RESULTS AND DISCUSSION Chemical Analysis}

The indicator of primary lipid oxidation was performed by changing the PV (Figure 1). The PV was increased progressively during the entire storage period until 8 days of storage. However, after 12 days of storage, the PV was decreased in all samples. This is a similar method to that used by Campos et al. (2006), where the PV of farmed turbot (Psetta maxima), in combined treatments of ozone and ice slurry and the ice slurry storage was used as the control increased over 7 days of storage and then decreased at 14 days of storage. After 14 days of storage, the PV increased to 21 days of storage. The interaction of the ozone concentration and the storage period were significantly different to the trend of $\mathrm{PV}$ in the red tilapia sample $(p<0.05)$ and was not significantly different in the short-bodied mackerel $(p>0.05)$. Based 


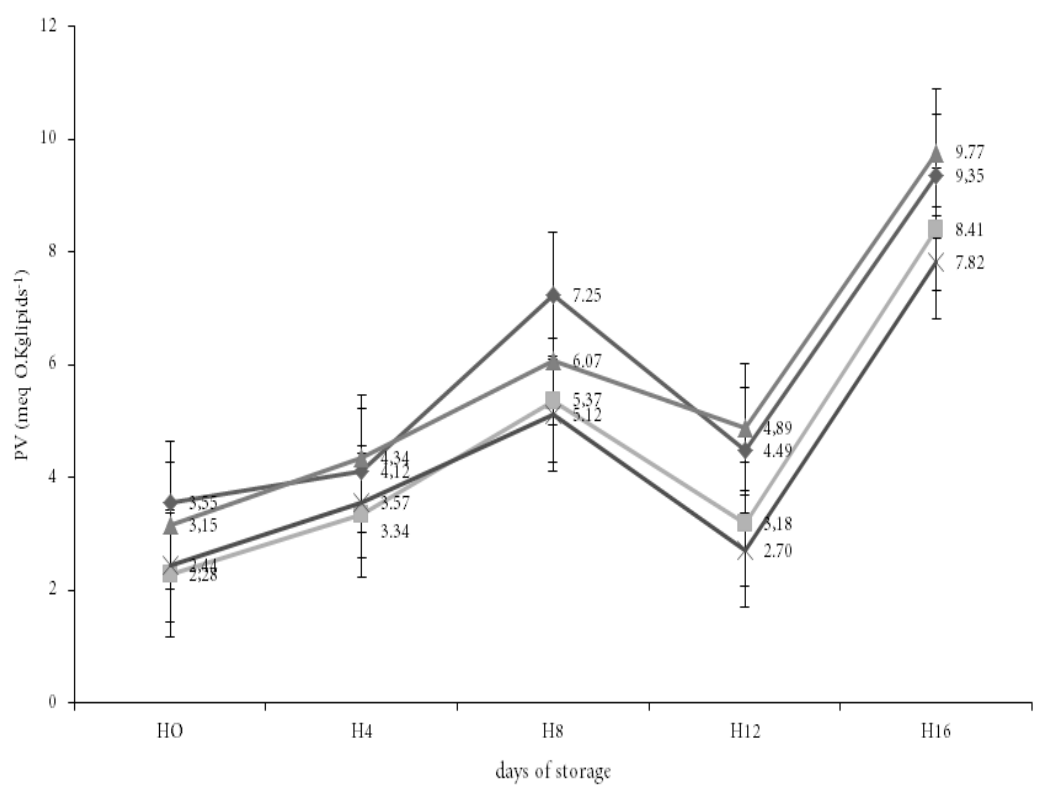

Figure 1. Changes in PV during storage of red tilapia and short-bodied mackerel. $\bullet=$ red tilapia first group; $\mathbf{\square}=$ red tilapia second group; $\boldsymbol{\Lambda}$ =short-bodied mackerel first group; $><=$ short-bodied mackerel second group

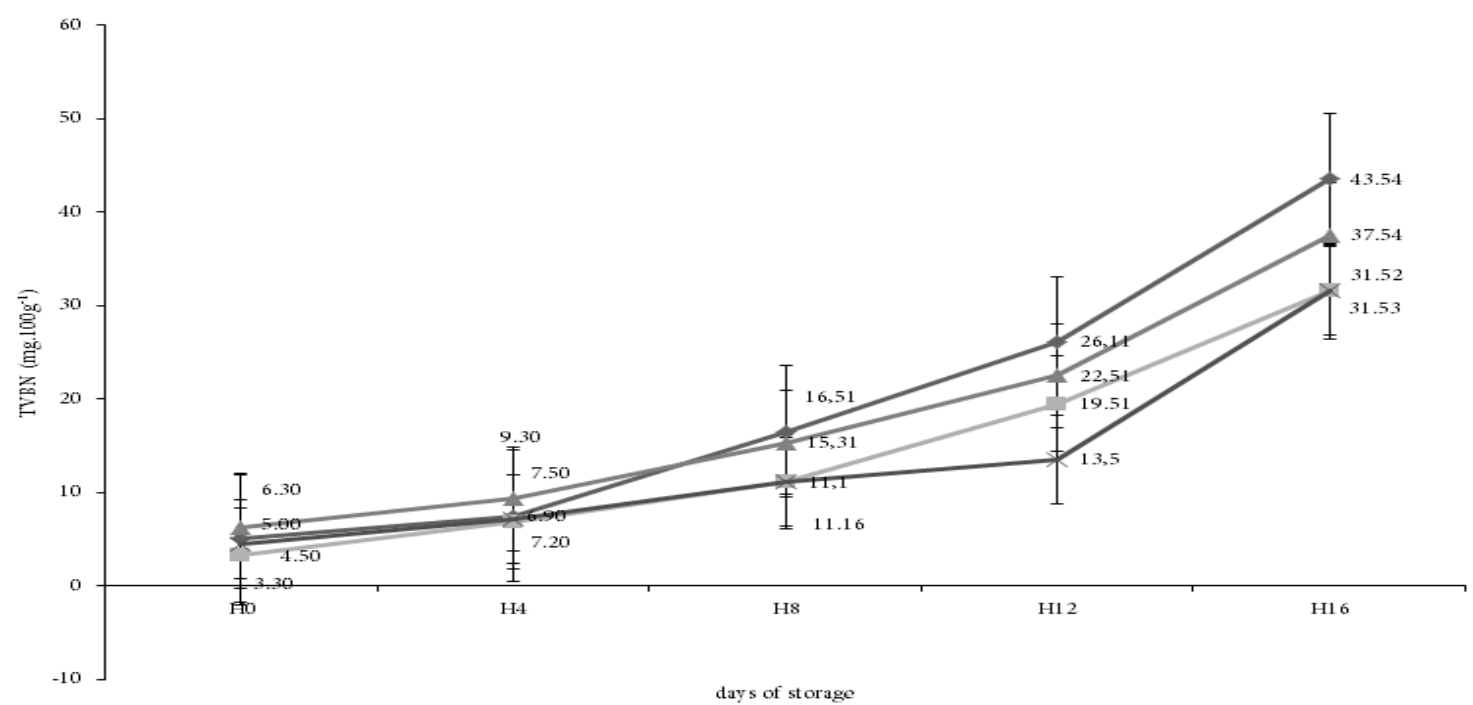

Figure 2. Changes in TVBN during storage of red tilapia and short-bodied mackerel. $\bullet=$ red tilapia first group; $\mathbf{\square}=$ red tilapia second group; $\boldsymbol{\Delta}$ =short-bodied mackerel first group; $><=$ short-bodied mackerel second group

on the PV limit of acceptability Agustini et al. (2012) the results of this study showed that all samples have a PV less than 20 meq.Kglipids ${ }^{-1}$; therefore, both fish species samples were accepted until 16 days of storage. Compared with the result of Bono and Badalucco (2012), the PV of packaged striped-red mullet (Mullus surmuletus) combined with MAP and ozone was rejected after 18 days of storage. It has been indicated that ozone applications showed a significant reduction in the rate of primary lipid oxidation and stated that ozone did not influence the pro-oxidative effect in shortbodied mackerel and red tilapia samples.

The results of TVBN in red tilapia and short-bodied mackerel during storage are provided in Figure 2. The TVBN showed an increasing trend in all samples through to the 
end of the storage period, the TVBN from 0 days is $3.3-6.3 \mathrm{mg} / 100 \mathrm{~g}$. Previously, a study by Nur et al. (2014), showed that the TVBN level of freshwater fish farmed after ozonized with $0.5 \mathrm{ppm}, 1 \mathrm{ppm}$, and $1.5 \mathrm{ppm}$ were in the range of 6 to $19 \mathrm{ppm}$, which is below the Indonesian National Standard for fresh fish (SNI:235.8:2009). According to Kyrana and Lougovois (2002), the acceptability the TVBN limit for fresh sea bass storage in melting ice was established as $25 \mathrm{mg} / 100 \mathrm{~g}$. The ozone concentration and storage period were significantly different to the formation of the TVBN in both samples $(p<0.05)$. The increasing trend of the TVBN in the end storage period was caused by microbiology activity in all the samples (Figure 2.). The TVBN produced by degradation of ammonia and other volatile amines from muscular tissues of the fish was based on microbiology activity. The higher TVBN level indicated a poor indicator of fish freshness, 16 days was the highest TVBN level in both samples. According to Manousaridis et al. (2005), the TVBN level of ozone in shucked mussels for 60 and $90 \mathrm{~min}$ increased to 24.2 and $26.9 \mathrm{mg} / 100 \mathrm{~g}$, respectively, on day $12 \mathrm{of}$ storage. Furthermore, Pastoriza et al. (2008), showed that hake (Merluccius merluccius) was washed with ozonized water (2 ppm) and stored at $2^{\circ} \mathrm{C}$ for 12 days where it was very close to the TVBN limit for rejection (24 $\mathrm{mg} / 100 \mathrm{~g}$ ). Moreover, Nerantzanki et al. (2005) showed that trout storage at $4^{\circ} \mathrm{C}$ after $90 \mathrm{~min}$ in ozonized water $(1 \mathrm{mg} / \mathrm{L})$ had a shelf-life of 12 days (limit of TVBN).

\section{Microbiological Analysis}

Changes of TVC in short-bodied mackerel and red tilapia are shown in Figure 3 . The ozone concentration was significantly different $(p<0.05)$ in short-bodied mackerel and red tilapia. The comparison of the TVC in the two species of samples with and without ozonized treatment was always higher in the non-ozonized samples. This indicated that ozonized treatment in two species of samples can reduce the growth of colony bacteria. The TVC values at 0 days of storage were 6.831 and $5.845 \log \mathrm{CFU}_{\mathrm{g}}{ }^{-1}$ on short-bodied mackerel sample without ozone treatment and short-bodied mackerel sample with ozone treatment, respectively, and in the end days of storage the TVC values were 8.578 and 7.786 $\log$ CFU.g ${ }^{-1}$,respectively. The TVC value in red tilapia without ozone treatment and red tilapia with the ozonized treatment at 0 days of storage were 5.839 and $5.399 \log$ CFU.g ${ }^{-1}$. At 16 days of storage, the TVC values were 8.271

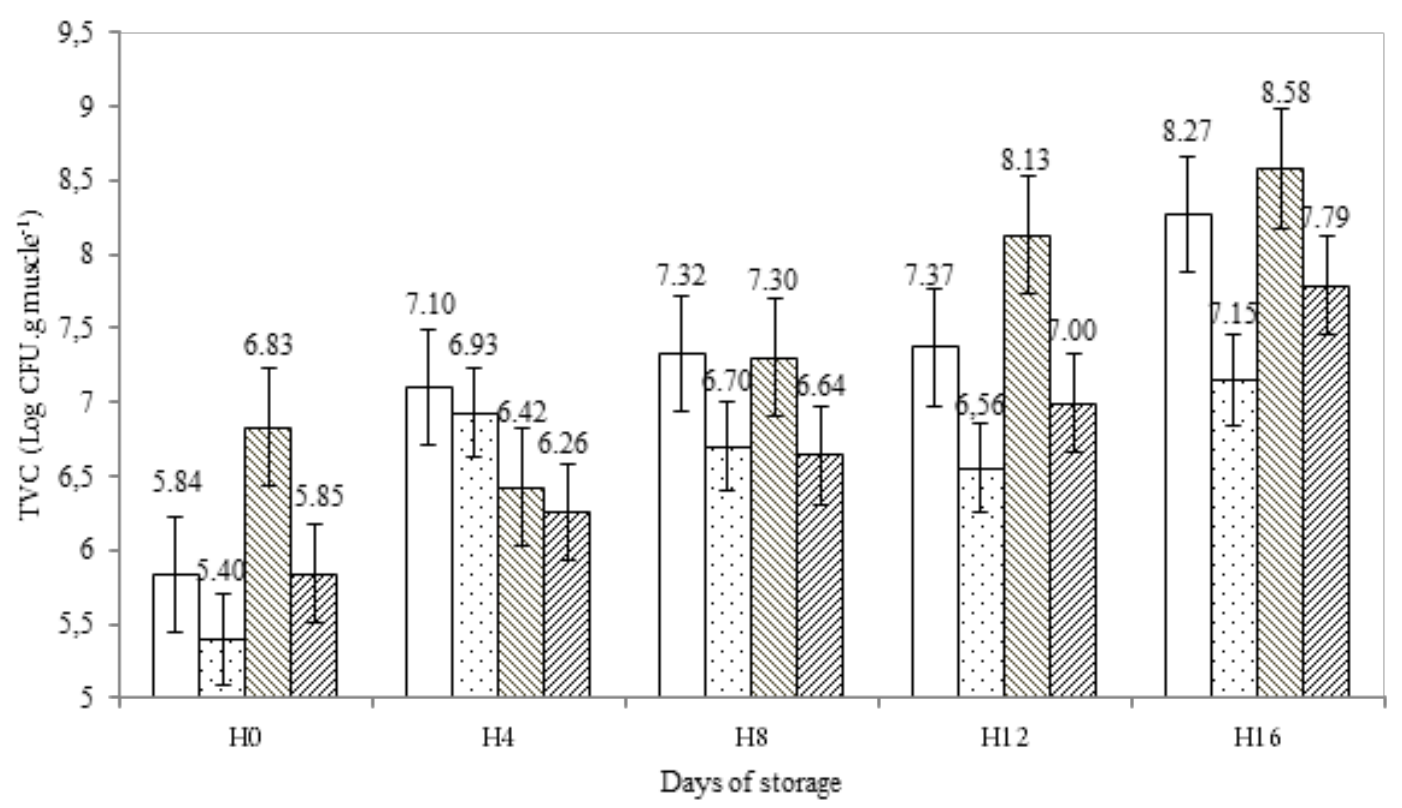

Figure 3. Changes in TVC during storage of red tilapia and short-bodied mackerel. $\square=$ red tilapia first group; $\cdot$ = red tilapia second group; $\mathbb{\mathbb { Q }}=$ short-bodied mackerel fisrt group; $\mathbb{\mathbb { Q }}=$ shortbodied mackerel second group. 
Table 1 . The sensory results of red tilapia and short-bodied mackerel

\begin{tabular}{|c|c|c|c|c|c|c|}
\hline \multirow{2}{*}{ Samples } & \multicolumn{6}{|c|}{ Parameters } \\
\hline & Eyes & Gills & Mucus & Consistency & Odor & Texture \\
\hline $00 \mathrm{RT}-0$ days & $8.6 \pm 0.52$ & $8.2 \pm 1.03$ & $8.6 \pm 0.97$ & $8.6 \pm 0.84$ & $8.4 \pm 0.97$ & $8.6 \pm 0.84$ \\
\hline $00 \mathrm{RT}$ - 4 days & $8.5 \pm 0.53$ & $8.2 \pm 0.42$ & $8.6 \pm 0.85$ & $8.4 \pm 0.84$ & $8.3 \pm 0.82$ & $8.5 \pm 0.85$ \\
\hline $00 \mathrm{RT}-8$ days & $8.2 \pm 0.42$ & $7.9 \pm 0.32$ & $8.3 \pm 0.82$ & $8.2 \pm 0.79$ & $8.2 \pm 0.79$ & $8.3 \pm 0.82$ \\
\hline 00 RT - 12 days & $7.9 \pm 0.32$ & $7.6 \pm 0.52^{\mathrm{e}}$ & $7.9 \pm 0.88^{\mathrm{h}}$ & $7.8 \pm 0.79^{k}$ & $7.7 \pm 0.67$ & $8.0 \pm 0.67$ \\
\hline 00 RT - 16 days & $7.5 \pm 0.53^{\mathrm{a}}$ & $7.4 \pm 0.52^{\mathrm{f}}$ & $7.5 \pm 0.71^{\mathrm{i}}$ & $6.6 \pm 0.52^{1}$ & $6.7 \pm 0.48$ & $6.6 \pm 0.52^{\mathrm{r}}$ \\
\hline $01 \mathrm{RT}-0$ days & $8.7 \pm 0.48$ & $8.4 \pm 0.97$ & $8.6 \pm 0.84$ & $8.6 \pm 0.84$ & $8.4 \pm 0.97$ & $8.8 \pm 0.63$ \\
\hline $01 \mathrm{RT}-4$ days & $8.6 \pm 0.52$ & $8.4 \pm 0.52$ & $8.6 \pm 0.67$ & $8.5 \pm 0.85$ & $8.4 \pm 0.84$ & $8.7 \pm 0.67$ \\
\hline $01 \mathrm{RT}-8$ days & $8.4 \pm 0.52$ & $8.0 \pm 0.47$ & $8.3 \pm 0.67$ & $8.3 \pm 0.67$ & $8.3 \pm 0.82$ & $8.4 \pm 0.52$ \\
\hline 01 RT - 12 days & $8.1 \pm 0.32$ & $7.9 \pm 0.32^{\mathrm{e}}$ & $8.2 \pm 0.63^{\mathrm{h}}$ & $8.1 \pm 0.74^{\mathrm{k}}$ & $7.9 \pm 0.74$ & $8.1 \pm 0.32$ \\
\hline 01 RT - 16 days & $7.9 \pm 0.32^{\mathrm{a}}$ & $7.8 \pm 0.42^{\mathrm{f}}$ & $7.9 \pm 0.32^{\mathrm{i}}$ & $6.9 \pm 0.32^{1}$ & $6.9 \pm 0.32$ & $6.9 \pm 0.32^{\mathrm{r}}$ \\
\hline $00 \mathrm{SM}-0$ days & $8.6 \pm 0.52$ & $8.6 \pm 0.84$ & $8.6 \pm 0.84$ & $8.6 \pm 0.84$ & $8.6 \pm 0.84$ & $8.6 \pm 0.84$ \\
\hline $00 \mathrm{SM}-4$ days & $8.4 \pm 0.52$ & $8.6 \pm 0.52$ & $8.6 \pm 0.67$ & $8.6 \pm 0.70^{\mathrm{m}}$ & $8.6 \pm 0.70$ & $8.5 \pm 0.85$ \\
\hline $00 \mathrm{SM}-8$ days & $8.1 \pm 0.32^{\mathrm{b}}$ & $8.2 \pm 0.42$ & $8.2 \pm 0.63$ & $8.1 \pm 0.57$ & $8.4 \pm 0.70$ & $8.2 \pm 0.79$ \\
\hline 00 SM - 12 days & $7.8 \pm 0.42^{\mathrm{c}}$ & $7.9 \pm 0.42$ & $7.6 \pm 0.52^{j}$ & $7.7 \pm 0.48^{\circ}$ & $7.7 \pm 0.48$ & $7.7 \pm 0.48$ \\
\hline $00 \mathrm{SM}-16$ days & $7.3 \pm 0.48^{\mathrm{d}}$ & $7.3 \pm 0.48^{g}$ & $7.4 \pm 0.52$ & $6.6 \pm 0.52^{\mathrm{p}}$ & $6.6 \pm 0.32^{q}$ & $6.5 \pm 0.53^{\mathrm{s}}$ \\
\hline $01 \mathrm{SM}-0$ days & $8.8 \pm 0.42$ & $8.6 \pm 0.84$ & $8.4 \pm 1.03$ & $8.4 \pm 0.97$ & $8.6 \pm 0.84$ & $8.8 \pm 0.63$ \\
\hline $01 \mathrm{SM}-4$ days & $8.7 \pm 0.48$ & $8.6 \pm 0.52$ & $8.6 \pm 0.67$ & $8.3 \pm 0.93^{\mathrm{m}}$ & $8.6 \pm 0.52$ & $8.3 \pm 0.95$ \\
\hline 01 SM - 8 days & $8.5 \pm 0.53^{b}$ & $8.1 \pm 0.32$ & $8.3 \pm 0.67$ & $8.2 \pm 0.79$ & $8.5 \pm 0.53$ & $8.1 \pm 0.32$ \\
\hline $01 \mathrm{SM}-12$ days & $8.3 \pm 0.48^{c}$ & $7.9 \pm 0.32$ & $8.0 \pm 0.47^{j}$ & $6.9 \pm 0.32^{\circ}$ & $7.9 \pm 0.32$ & $7.9 \pm 0.32$ \\
\hline $01 \mathrm{SM}-16$ days & $7.8 \pm 0.42^{\mathrm{d}}$ & $7.7 \pm 0.48^{\mathrm{g}}$ & $7.7 \pm 0.48$ & $7.7 \pm 0.48^{p}$ & $6.9 \pm 0.32^{\mathrm{q}}$ & $6.9 \pm 0.32^{s}$ \\
\hline
\end{tabular}

Note: 00 RT (first group of red tilapia), 01 RT (second group of red tilapia), 00 SM (first group of short-bodied mackerel), 01 SM (second group of short-bodied mackerel), values were followed by same superscript shown significant differences.

and $7.152 \log \mathrm{CFU} . \mathrm{g}^{-1}$ respectively.The same reports were found by Campos et al. (2006), where they used ozone coupled with ice slurry and the microbial growth on the surface of turn about occurred more slowly compared with the ice slurry treatment only. Based on Bono and Badalucco (2012), the maximum TVC limit for fresh marine fish was $6 \log$ CFU. $\mathrm{g}^{-1}$ which was reached after 9 days of storage for MAP and MAP with ozone treatments of striped-red mullet.

\section{Microbiological Analysis}

Applying ozone was significantly different from the sensory value of red tilapia and shortbodied mackerel $(p<0.05)$. The sensory level of the fish samples was lower for the fish samples with ozone treatment (Table 1). This is similar to Goncalves (2009), that the sensory level of the products with ozone treatment was much better; the fungal growth, bacteria, and deterioration could be inhibited by the ozone. The ozone molecules affect the intracellular enzyme, nucleic acid, and other components of the microbe. Based on the Indonesian National Standard 2729:2013, the minimum level of rejected fish was 7; overall, the sensory value of the samples until 16 days of storage was still upward of 7 but the consistency, odor, and texture indicated they were rejected in 16 days. This correlates with the TVBN of all samples rejected after 16 days of storage. The TVBN resulted through microbe activity which degraded the nitrogenous properties in the muscles of the fish producing ammonia. These are similar results with Gelman et al. (2006), where tilapia was injected with 0.1 ppm stored at $0^{\circ} \mathrm{C}$ and still had good quality until 30 days of storage. Other researchers,[2] and [3], used shucked mussels which were treated with $0.4 \mathrm{ppm}$ ozonized water solution for $90 \mathrm{~min}$ and the odor, taste, and texture was 
still acceptable until 12 days of storage. The farmed turbot (Psetta maxima) with ozonized ice slurry provided an acceptable sensory level until 28 days of storage.

\section{CONCLUSION}

An ozone and slurry ice treatment combined system with different concentrations had a significant $(p<0.05)$ effect on the TVBN, the PV, and the TVC. The interaction of ozone and slurry ice provided no significant different $(p>0.05)$ in both samples. The sensory evaluation in both samples showed a good correlation with TVC. This study showed that ozone and slurry ice could maintain the samples freshness during storage.

\section{ACKNOWLEDGEMENTS}

The authors would like to acknowledge the Ministry of Research and Technology through Incentive Research Sinas Program 2013 in providing a grant for this study.

\section{REFERENCES}

Agustini, T.W, Eko S, Ismail M.A. and Mohammad Shafiur R. 2012. Effect of Aloe vera (Alloe vera) and crown of god fruit (Phaleria macrocarpa) on sensory, chemical and microbiological attributes of Indian mackerel (Restrelliger neglectus) during ice storage. International Food Research Journal. 19(1): 119-125.

AOCS. American Oils Chemists Society. 1995. Official Methods and Recommended Practices of the American Oil Chemists Society. Champaign. AOCS Press.

Bono G, Badalucco C. 2012. Combining ozone and modified atmosphere packaging (MAP) to maximize shelf-life and quality of striped red mullet (Mullussur muletus). LWT-Food Science and Technology. 47: 500-504.

Campos CA, Losada V, Rodriguez O, Auborg SP, Barros-Velazquez J. 2006. Evaluation of an ozone-slurry ice combined refrigeration system for the storage of farmed turbot (Psetta maxima). Food Chemistry. 97: 223-230.

Crowe KM, Skonberg D, Bushway Al, Baxter S. 2012. Application of ozone sprays as a strategy to improve the microbial safety and quality of salmon filets. Food Control. 25: 404-408.

Delagado-Lista J, Perez-Martinez P, LopezMiranda J, Perez-Jimenez F. 2012. Long chain omega-3 fatty acids and cardiovascular disease : a systematic review. British Journal of Nutrition. 107 (2). 201-213.

Goncalves AA. 2009. Ozone-an emerging technology for the seafood industry. $J$. Braz. Arch. Biol Technol. 52(6): 15271539.

Gelman AL, Glatman O, Sachs Y, Khanin and Drabkin, v. 2006. Ozone action on survival and storage life of live and chilled tilapia. The Israel Journal Aquaculture Bamidgeh. 58(3): 147-156.

Kyrana VR and Lougovois VP. 2002. Sensory, chemical and microbiological assessment of farm-raised European sea bass (Dicentrarchus labrax) storage in melting ice. International Journal of Food Science and Technology. 37: 319-328.

Leksono S. 2001. The study of the quality of and acceptance of the customers to Abon. Jurnal Indonesia Natur. 3(2): 178-184.

Manousaridis G, Nerantzaki A, Paleologos EK, Tsiotsia A, Savvidis IN, Kontominas MG. 2005. Effect ozone on microbial, chemical and sensory attributes of shucked mussels. Food Microbiology. 22: 1-9.

Ministry of Maritime Affairs and Fisheries. 2015a. Marine and fisheries in Figures 2015. Data, Stastistic and Information Center. Ministry of Maritime Affairs and Fisheries. Jakarta. 310p.

Ministry of Maritime Affairs and Fisheries. 2015b. Primary data analysis. Data, Stastistic and Information Center. Jakarta (ID): Ministry of Maritime Affairs and Fisheries.

Nerantzaki A, Tsiotsias A, Paleologos EK, Savvidis IN, Beritzoglou E, Kontominas MG. 2005. Effects of ozonation on microbiological, chemical and sensory attributes of vacuum-packed rainbow trout stored at $4^{\circ} \mathrm{C}$. European Food Research and Technology. 221: 675-683.

Nurjanah, Setyaningsih, Sukarno, Muldani M. 2004. Kemunduran Mutu Ikan Oreochromis sp. selama penyimpanan 
pada suhu ruang. Buletin Teknologi Hasil Perikanan. 7(1): 37-43. DOI: http:// dx.doi.org/10.17844/jphpi.v7i1.1056.

Nur M, Resti M, Arianto F, Muhlisin Z, Teke S, Susan AI, Kusdiyantini E, Wuryanti, Winarni TA, Susilo, Muharam M. 2014. Development of ozone technology fish storage systems for improving quality fish production. International Symposium on Technology Management and Emerging Technologies (ISTMET) 2014. IEEE
Xplore. DOI : http://dx.doi.org/10.1109/ ISTMET.2014.6936500.

Pastoriza L, Bernandez M, Sampedro G, Cabo ML, Herrera JJR. 2008. Use of sterile and ozonized water as a strategy to stabilize the quality of storage refrigerated fresh fish. Food Chemistry. 19: 772-780.

Perica MM and Delas I. 2011. Essential fatty acids and psychiatric disorders. Nutrition in Clinical Practice. 26(4): 409-425.

Pineiro C, Barros-Velazques J and Auborg SP. 2004. Effects of newer slurry ice systems on the quality of aquatic food products: a comparative review versus flake ice chilling methods. Trend in Food Science and Technology. 15. 575-582. 